\title{
Institutions and inequality interplay shapes the impact of economic growth on biodiversity loss
}

\author{
M. Usman Mirza ${ }^{1,2}$ Andries Richter $^{3,4}$ Egbert H. van Nes $^{2}$ and Marten Scheffer $^{2}$
}

\begin{abstract}
The latest global assessment of the Intergovernmental Science-Policy Platform on Biodiversity and Ecosystem Services (IPBES) warns that biodiversity loss can make ecosystems more vulnerable to the effects of climate change and other stressors. Economic growth has been identified as one of the key drivers of these losses, however, the impact pathway may depend on how society organizes economic activity and distributes its benefits. Here we use a global country-level dataset to show how the strength of national institutions and economic inequality in society can mediate the loss of biodiversity worldwide. We find that the interplay of institutions and inequality fully mediates the impact of economic growth on plant biodiversity, but only partially mediates the impact on animal biodiversity. Furthermore, in sustaining biodiversity, the effectiveness of institutions depends on inequality in society, such that biodiversity loss is ameliorated when institutions are strong and inequality low, but in regions with high inequality, institutions tend to lose their efficacy. The analysis also uncovers nonlinearities in inequality, institutions, and biodiversity interactions, which are important to investigate further and consider for policy purposes.
\end{abstract}

Key Words: biodiversity; inequality; institutions; nonlinear relationships; socioeconomic processes; sustainability

\section{INTRODUCTION}

Today biodiversity is declining globally faster than at any time in our history (Bongaarts 2019). Anthropogenic drivers put unprecedented pressures on our planet, resulting in biodiversity loss and exploitation of renewable resources beyond sustainable limits (Rockström et al. 2009, Bongaarts 2019). Biosphere impacts of societies are inherently social-ecological in nature with complex interactions and feedbacks (Ostrom 2009, Steffen et al. 2018). Earlier work has shown the detrimental effect of economic drivers, in particular, economic growth, on the biosphere (Naidoo and Adamowicz 2001, Dietz and Adger 2003, Asafu-Adjaye 2003, Mikkelson et al. 2007, Holland et al. 2009, Mills and Waite 2009). At the same time, economic growth creates wealth, which may give societies the means to mitigate biosphere impacts (Mirza et al. 2019) and ultimately foster Earth stewardship (Folke et al. 2011).

The exact impacts of economic growth are therefore ambiguous because the biosphere impacts are mediated through societal mechanisms, such as quality of institutions (Leach et al. 1999, Klooster 2000) and incidence of economic inequality (Boyce 1994, Heerink et al. 2001). The success of formal institutions in addressing the environmental toll of unsustainable economic activity depends crucially on the level of inequality in society. For instance, less developed nations, especially, are often plagued with weak institutional structures and skewed economic returns to the wealthy, making collective action for biodiversity restoration difficult and causing exploitative growth at the expense of the environment (Bongaarts 2019).

It is widely known now that economic development does not translate into biosphere stewardship, without sound institutional mechanisms steering economic activity (Arrow et al. 1996). Indeed, economic growth does not ensure environmental quality (Shafik 1994, Grossman and Krueger 1995) because there are multiple mediating factors, such as the strength of institutions and how uniformly the benefits of growth are distributed, that determine how economic growth impacts the environment. Evidence suggests that these mediating factors influence each other, such that high inequality undermines institutional quality or conversely poor institutions allow inequality to flourish, potentially creating a positive feedback that multiplies detrimental effects on the biosphere (Easterly et al. 2006, Mehlum et al. 2006). High inequality tends to concentrate economic power within a select few who can circumvent rules, impeding efforts to halt biodiversity loss. Most of the existing work focuses on direct single variable effects, with little or no insights on interactions and indirect paths (Carpenter et al. 2009, Mazor et al. 2018), while the literature suggests that inequality and institutions move together in a bidirectional cause-effect relationship (Chong and Calderón 2000, Chong and Gradstein 2007, Rogowski and MacRae 2008), and there are pronounced nonlinearities between inequality and environmental linkages (Mikkelson et al. 2007, Holland et al. 2009).

In this paper, we use a global country-level panel dataset to analyze the role of income inequality and strength of institutions, in explaining the biosphere impacts of economic growth. We study how the interplay between institutions and inequality mediates the impacts of economic growth on biodiversity loss. Considering its social and ecological significance (Hooper et al. 2012), we use biodiversity loss as the key biosphere impact variable. Diversity of animals and plants in the biosphere is changing slowly, but has a high impact on the functioning of our ecosystem and its ability to provide society means to prosperity (Cardinale et al. 2012). In addition to the instrumental value to society, biodiversity inherits an intrinsic value rooted in what Soule (1985) refers to as the "inherent value of nonhuman life." In this day and age where the unfettered economic growth by humans infringe upon the interest of nonhuman species, the rules of coexistence should consider

${ }^{1}$ School of Business and Economics, Maastricht University, ${ }^{2}$ Environmental Sciences, Wageningen University, ${ }^{3}$ Environmental Economics and Natural Resources Group, Sub-department of Economics, Wageningen University, ${ }^{4}$ Centre for Ecological and Evolutionary Synthesis, Department of Biosciences, University of Oslo 
both the utilitarian and intrinsic value as foundational axioms of biodiversity conservation (Vucetich et al. 2015). For tractability demands and empirical nature of our analysis, we limit our focus to consider drivers of biodiversity loss that are multivariate and nonlinear in nature, with both direct and indirect pathways from human economic activity and our social structures. For the interested reader, we refer to the following related recent literature concerning economic growth and the intrinsic nature of biodiversity (Dasgupta et al. 2013, Apostolopoulou and Adams 2017, Brum et al. 2017, Crist et al. 2017, Washington and Maloney 2020).

We start with a conceptual model (Fig. 1), hypothesizing key relationships. Economic growth spurs output (GDP per capita), which can have both direct and indirect effects based on the impact pathway. Although economic growth may affect biodiversity directly, there are also indirect effects mediated through air pollution and resource use that can build strain on a much slower variable like biodiversity. In parallel, there can be more indirect routes via the evolution of societal variables like income inequality and the strength of institutions, which affects pollution and resource use, in turn affecting biodiversity. We use a combination of generalized additive (GAM) and structural equations models (SEM) to investigate these and other impact pathways systematically. Within the SEM framework, additional covariates and generalized method of moments (GMM; Blundell and Bond 1998) estimators are used to control for confounding variables and reverse causation.

Fig. 1. Direct and indirect effect pathways from economic growth to biodiversity loss. A conceptual model illustrating the structural relationship.

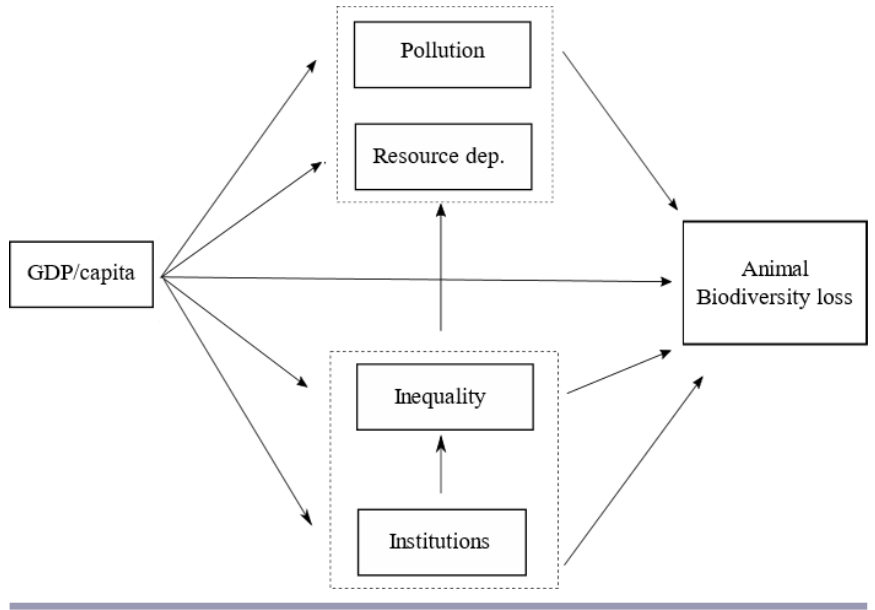

\section{METHODS}

\section{Data}

The dataset used in the analysis is built from multiple sources including the IUCN's Red List of Threatened Species, World Bank's Development Indicators, The Standardized World Income Inequality Database, World Bank's Governance Indicators, and University of East Anglia' Climatic Research Unit (UEA CRU). Capturing biodiversity loss is not straight forward. Only a fraction of all species have been taxonomically classified and there are large variations in species richness across countries that are determined by local country-specific habitat and environment. Thus is it important that we define biodiversity loss taking into account species richness and include observable country-specific fixed effects in this analysis. A description of all variables is given in Table 1. Variables in the panel data set include available observations in the time range 2010-2015 and from a cross-section of at least 58 countries globally. Biodiversity loss of animals and plants constitute key outcome variables and are log-transformed to standardize and aid comparison.

Income inequality and institutional strength are core mediating and explanatory variables of interest. Income inequality is quantified by the widely used standardized index of Gini coefficients (Gini 1912). No similar widely accepted estimate exists for institutional strength. To construct a standardized indicator we use principal component analysis (PCA) on six national-level World Bank's governance indicators that reflect the strength of institutions. Although highly correlated, these indicators all measure different dimensions such as voice and accountability, political stability and absence of violence, government effectiveness, regulatory quality, rule of law, and control of corruption. We standardized these six dimensions into a single measure of institutional strength by using their first principal component. PCA is an unsupervised dimension reduction technique, which parses data into orthogonal components thus capturing most of the variation in the first component(s), with further components explaining the decrease in the percentage of variance (Fig. 2). The first component, which we term as institutional strength, captures $84.7 \%$ of the variance over the country's regulatory quality, control of corruption, governance effectiveness, and rule of law.

Fig. 2. Principal component analysis (a) and correlation plot (b) for institutional quality variables.
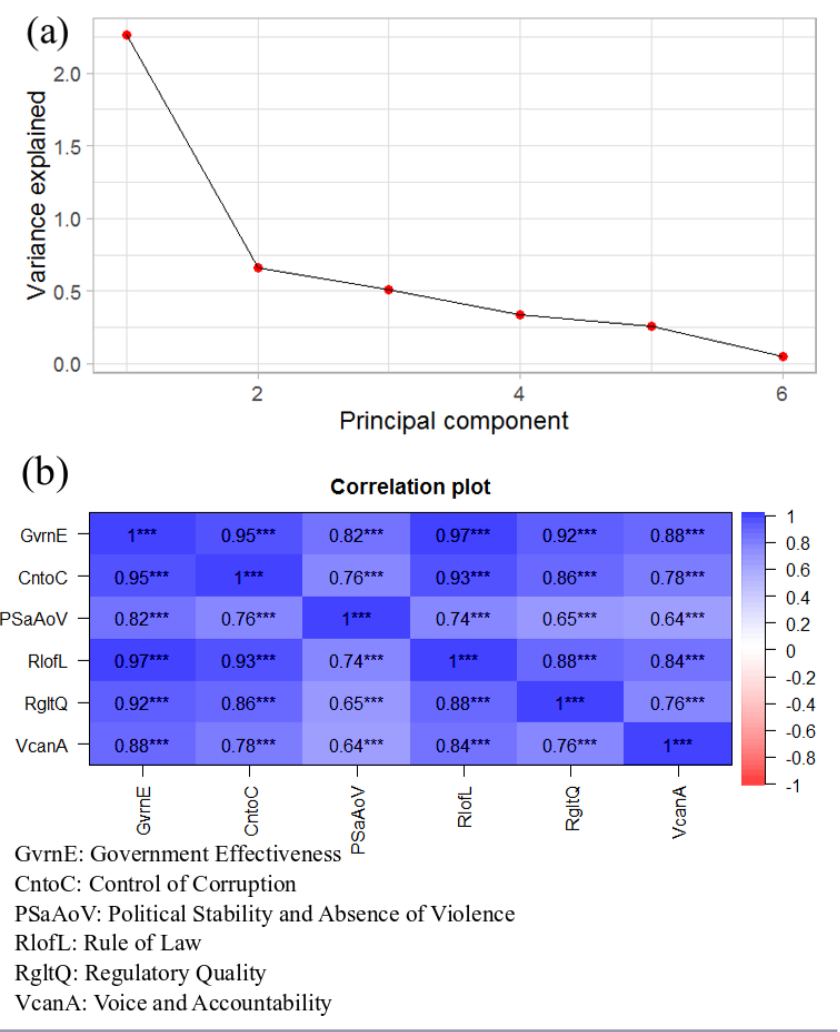
Table 1. Data set description of variables.

\begin{tabular}{|c|c|c|c|}
\hline Variables & Units & Description & Source \\
\hline Inequality & Unit-less & Gini coefficient & $\begin{array}{l}\text { Standardized World } \\
\text { Income Inequality } \\
\text { Database }\end{array}$ \\
\hline Institutions & Unit-less & World governance indicators & $\begin{array}{l}\text { World Bank's } \\
\text { Governance Indicators }\end{array}$ \\
\hline Economic growth & Rate & GDP per capita growth (annual \%) & $\begin{array}{l}\text { World Bank's } \\
\text { Development Indicators }\end{array}$ \\
\hline $\begin{array}{l}\text { Animal biodiversity } \\
\text { loss }\end{array}$ & Ratio & Ratio of threatened species to total number of species identified. & IUCN's Red List \\
\hline $\begin{array}{l}\text { Plant biodiversity } \\
\text { loss }\end{array}$ & Ratio & Ratio of threatened species to total number of species identified. & IUCN's Red List \\
\hline Temperature & Celsius & Mean temperature for the country. & $\begin{array}{l}\text { Climatic Research Unit, } \\
\text { UEA }\end{array}$ \\
\hline Precipitation & Volume (Millimetre) & Total precipitation for the country. & $\begin{array}{l}\text { Climatic Research Unit, } \\
\text { UEA }\end{array}$ \\
\hline Surface area & Area (kilometer $\left.{ }^{2}\right)$ & $\begin{array}{l}\text { Surface area is a country's total area, including areas under inland bodies } \\
\text { of water and some coastal waterways. }\end{array}$ & $\begin{array}{l}\text { World Bank's } \\
\text { Development Indicators }\end{array}$ \\
\hline Population & Count (sum) & $\begin{array}{l}\text { Total population counting all residents regardless of legal status or } \\
\text { citizenship. }\end{array}$ & $\begin{array}{l}\text { World Bank's } \\
\text { Development Indicators }\end{array}$ \\
\hline Pollution & $\begin{array}{l}\text { PM2.5 air pollution, mean } \\
\text { annual exposure } \\
\text { (micrograms per cubic } \\
\text { meter) }\end{array}$ & $\begin{array}{l}\text { Population-weighted exposure to ambient PM } 2.5 \text { pollution is defined as } \\
\text { the average level of exposure of a nation's population to concentrations of } \\
\text { suspended particles measuring less than } 2.5 \text { microns in aerodynamic } \\
\text { diameter. }\end{array}$ & $\begin{array}{l}\text { World Bank's } \\
\text { Development Indicators }\end{array}$ \\
\hline Resource depletion & Natural resources depletion & $\begin{array}{l}\text { Natural resource depletion is the sum of net forest depletion, energy } \\
\text { depletion, and mineral depletion. }\end{array}$ & $\begin{array}{l}\text { World Bank's } \\
\text { Development Indicators }\end{array}$ \\
\hline
\end{tabular}

In addition to the mediating effects via inequality and institutions, economic growth also has more direct impacts on biodiversity that need to be considered. These include processes like pollution, population growth, and resource exploitation that undermine conservation efforts and can trigger habitat loss (Asafu-Adjaye 2003, Dietz and Adger 2003). Here we use air pollution and natural resource depletion as two available proxies to capture direct impacts of economic growth. Furthermore, as noted earlier, there is also a need to control for country-specific factors that influence local habitat. Thus, a number of available covariates are used to control for other observable factors that may affect biodiversity loss. These include temperature, precipitation, country surface area, country population, and income.

\section{Model}

With the data set up, the analysis proceeds in two steps. First, we explore suspected nonlinearities in the institutions-inequality space using a GAM. GAM is a generalization of the multiple linear regression model, where linear terms are replaced by nonparametric function(s) of the predictor, to allow for complex nonlinear relationships to be estimated and thereby achieving the best possible prediction of the outcome variable (Wood 2017). Separate models were fitted for biodiversity loss (plants), and biodiversity loss (animals) as response variables. The general GAM structure used is as follows:

$$
\begin{gathered}
B_{i j}=\beta_{0}+f_{1}\left(Q_{i j}, S_{i j}\right) * Y+f_{n}(X)+\varepsilon_{i j} \\
f_{n}(X)=f_{2}\left(I_{i j}\right)+f_{4}\left(O_{i j}\right)+f_{5}\left(U_{i j}\right)+f_{7}\left(T_{i j}\right)+f_{8}\left(P_{i j}\right)+ \\
f_{9}\left(D_{i j}\right)+f_{10}\left(A_{i}\right)+Y \\
\varepsilon_{i j} \sim N\left(0, \sigma^{2}\right)
\end{gathered}
$$

Subscript $i j$ refers to observations of country $i$ in year $j$. Here $B$ is the chosen log biodiversity loss (animals or plants) response variable and $Q$ and $S$ are key explanatory variables of interest denoting inequality and institutional quality respectively. $I$ is $\log$ income, $O$ is $\log$ population, $U$ is $\log$ pollution, $T$ is temperature, $P$ is $\log$ precipitation, $D$ is $\log$ natural resource depletion, $A$ is $\log$ country surface area, and $Y$ is years. $f(Q, S)$ is a smoothing function using tensor product smooths. Tensor product smooths are used for smooth interaction of two or more variables especially when they are measured in different units. The basic idea is to start with "smooths" in one variable with any basis functions and then construct products by varying in the other dimension to get Equation 2 (Wood 2006):

$$
f_{1}(Q, S)=\sum_{l=1}^{L} \sum_{m=1}^{M} \alpha_{l m} b_{l}(Q) c_{m}(S)
$$

$L$ and $M$ are the dimensions or degrees of freedom of $b \_i$ and $c \_i$, the smoothing basis functions. $a_{-} i j$ is the vector of unknown regression coefficients. For the rest we have the following standard smoothing structure (Eqn 3):

$$
f_{n}(X)=\sum_{k=1}^{K} \beta_{k n} d_{k n}(X)
$$

Basis dimensions $(L, M, K)$ are restricted to 3 to limit oversmoothing.

Second, having predicted the general structure, we now move to structurally estimate the individual relationships in the earlier introduced conceptual model (Fig. 1). A structural equation model (SEM) framework is used to statistically test specific 
interactions. SEM is multiple simultaneously estimated regression models in which the response variable in one regression equation can appear as an explanatory variable in another equation (Grace 2006). Global or simultaneous estimation of SEMs assumes a number of restriction on the underlying data structure such as linearity, normality, and one-way effects. A more powerful and flexible approach is piecewise estimation (Lefcheck 2016), where each model is fitted separately, such that the complexity of each relation can be addressed individually.

Utilizing the piecewise SEM framework, we use a combination of panel regressions and GMM (generalized method of moments) estimators, to control for unobserved heterogeneity across countries, and suspected endogeneity within modeled relations. The estimated equations, for direct and indirect effects, are as follows:

For animal biodiversity loss:

Direct effects:

$$
\begin{aligned}
B_{i j}= & \beta_{0}+\beta_{1} Q_{i j}+\beta_{2} Q_{i j}^{2}+\beta_{3} S_{i j}+\beta_{4} S_{i j}^{2}+\beta_{5} I_{i j}+ \\
& \beta_{6} O_{i j}+\beta_{7} U_{i j}+\beta_{8} A_{i}+\beta_{9} D_{i}+\mu_{j}+\varepsilon_{i j}
\end{aligned}
$$

Indirect effects:

$$
\begin{gathered}
S_{i j}=\beta_{0}+\beta_{1} I_{i j}+\beta_{2} O_{i j}+v_{i}+\mu_{\mathrm{j}}+\varepsilon_{i j} \\
Q_{i j}=\beta_{0}+\beta_{1} I_{i j}+\beta_{2} S_{i j}+\beta_{3} O_{i j}+\beta_{4} U_{i j}+\beta_{5} D_{i j}+ \\
v_{i}+\mu_{\mathrm{j}}+\varepsilon_{i j} \\
D_{i j}=\beta_{0}+\beta_{1} I_{i j}+\beta_{2} Q_{i j}+v_{i}+\mu_{\mathrm{j}}+\varepsilon_{i j} \\
U_{i j}=\beta_{0}+\beta_{1} I_{i j}+\beta_{2} Q_{i j}+v_{i}+\mu_{\mathrm{j}}+\varepsilon_{i j}
\end{gathered}
$$

For plant biodiversity loss.

Direct effects:

$$
\begin{aligned}
B_{i j}= & \beta_{0}+\beta_{1} Q_{i j}+\beta_{2} Q_{i j}^{2}+\beta_{3} S_{i j}+\beta_{4} S_{i j}^{2}+\beta_{5} I_{i j}+ \\
& \beta_{6} O_{i j}+\beta_{7} P_{i j}+\beta_{8} A_{i}+\beta_{9} D_{i}+\mu_{j}+\varepsilon_{i j}
\end{aligned}
$$

Indirect effects:

$$
\begin{gathered}
S_{i j}=\beta_{0}+\beta_{1} I_{i j}+\beta_{2} O_{i j}+v_{i}+\mu_{\mathrm{j}}+\varepsilon_{i j} \\
Q_{i j}=\beta_{0}+\beta_{1} I_{i j}+\beta_{2} S_{i j}+\beta_{3} O_{i j}+\beta_{4} U_{i j}+\beta_{5} D_{i j}+ \\
v_{i}+\mu_{\mathrm{j}}+\varepsilon_{i j} \\
D_{i j}=\beta_{0}+\beta_{1} I_{i j}+\beta_{2} Q_{i j}+v_{i}+\mu_{\mathrm{j}}+\varepsilon_{i j} \\
U_{i j}=\beta_{0}+\beta_{1} I_{i j}+\beta_{2} Q_{i j}+v_{i}+\mu_{\mathrm{j}}+\varepsilon_{i j}
\end{gathered}
$$

As before, subscript $i j$ refers to the individual (country) and time (years) dimensions respectively. Because biodiversity loss is a slow variable, we estimated Equations 4 and 6 using time fixed effects panel estimates, to control for any unobserved heterogeneity across time. Time invariant covariate such as country surface area was included to absorb individual country level heterogeneity.

Equation sets 5 and 7 contain variables potentially posing an endogeneity problem due to simultaneity bias, such as between inequality and institutions, between inequality and natural resource depletion and between inequality and pollution. To deal with endogeneity, we use lagged transformations of the endogenous variables as instruments in a two-step Blundell and Bond (Blundell and Bond 1998) type system GMM estimator with robust standard errors (Windmeijer 2005). Within the GMM estimator, a two-way individual and time fixed effects model was applied, taking into account both heterogeneity across countries and time in the analysis. Fixed as opposed to a random model specification was chosen based on the Hausman test, which rejected the null hypothesis of random effects with a p-value $<$ 0.001 .

\section{RESULTS}

Before we present results on biodiversity loss, as the key outcome variable, it is important to understand how inequality and institutions interact with each other. A simple inspection of the data, pooled on the level of countries, reveals a nonlinear inverted U-shaped relationship between institutional strength and inequality (Fig. 3). As we move from areas of low to high institutional strength, inequality first rises but then drops. Variation in the data here include cross-country heterogeneity but the U-shaped specification is robust when we include countryspecific fixed effects as well. The turning point where inequality is highest is seen for countries where institutions are at intermediate strength, while both low and high institutional strength areas have low inequality.

Fig. 3. The relationship between inequality-institutional interaction in the data across countries resembles an inverted $\mathrm{U}$.

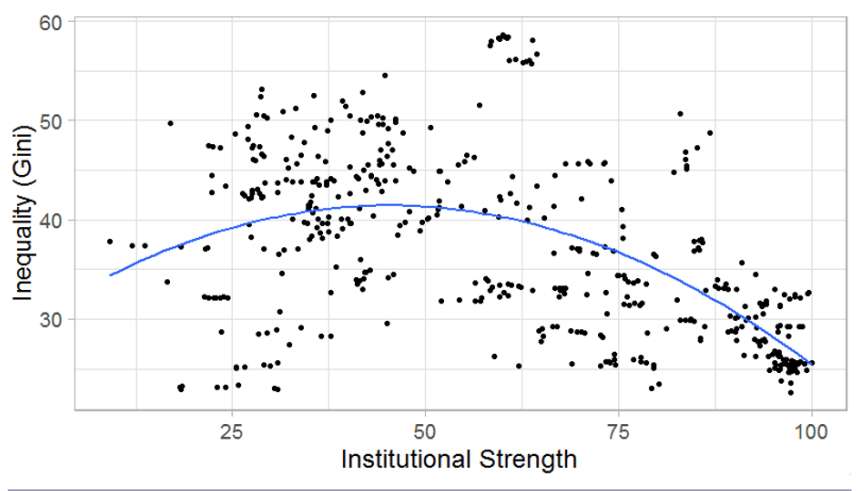

Exploring the nonlinearity further, we model inequalityinstitutions interactions against biodiversity loss, using generalized additive models, allowing us to investigate the underlying relationship. At the margins, we see an inverted Ushaped relationship for institutions and a positive relationship for inequality, with respect to animal biodiversity loss (Fig. 4a). Biodiversity loss worsens as inequality rises, and this worsening effect is strongest if institutions are in a developing phase. The result highlights the insidious nature of high inequality, such that 
income concentrated in a few hands is able to circumvent a still evolving institutional setup. On the other hand, when inequality is low, institutions are effective in improving biodiversity, even when still nascent. In general, biodiversity loss is predicted to be lowest when institutions are strong and inequality is low.

Fig. 4. Trends in biodiversity loss due to inherent nonlinearities in inequality-institutions space. Red to blue regions show high to low biodiversity loss respectively. Biodiversity loss values predicted using a generalized additive model (GAM) with inequality-institutions interactions.

(a)
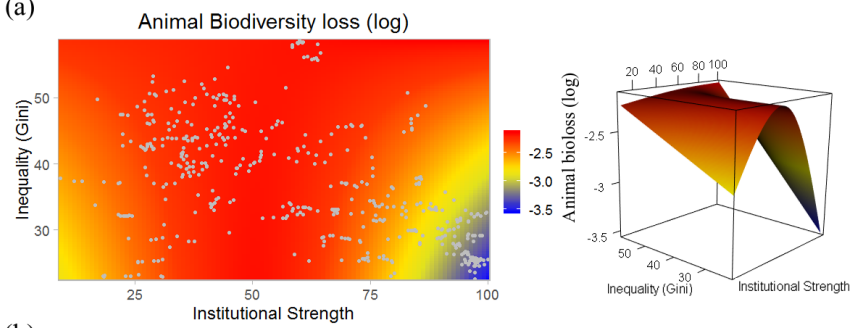

(b)

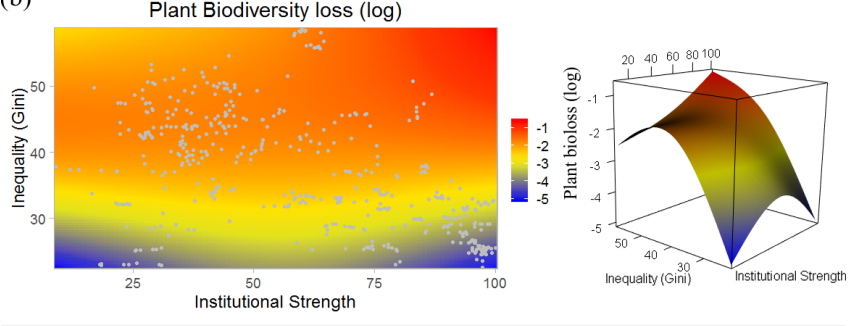

A similar pattern emerges for plant biodiversity loss (Fig. 4b). An inverted U-shaped relationship is apparent along the institutions' axis, where low or high levels of institutional quality lead to less biodiversity loss. Higher inequality tends to be associated with greater biodiversity loss. A common feature in both plant and animal biodiversity results is that we see a consistent pattern of institutional efficacy waning in the face of high inequality, while the combination of strong institutions and low inequality being the most effective way to curb biodiversity loss. Also, in general, biodiversity loss worsens, as inequality rises, irrespective of institutional strength.

Having analyzed the general relationship of how institutions and inequality interact with biodiversity loss, we now explore specific impact pathways in the economic growth-biodiversity loss relationship, using the SEM meta-model as introduced in Figure 1a. Direct and indirect effect pathways for animal and plant biodiversity loss are summarized graphically in Figure 5 and model estimates respectively in Tables 2 and 3 . We only report statistically significant effects here, as defined by the coefficient's p-values. By direct effect, we refer to a significant relationship in the model explaining animals and plant biodiversity loss (Model 1 in Tables 2 and 3), after controlling for confounding factors. A direct effect is illustrated by an uninterrupted link between two variables (Fig. 5). Indirect effects are significant relationships mediated by intermediate variables, such as those explained by models 2-5 in Tables 2 and 3. An indirect effect is illustrated by a link through the respective mediating variable (Fig. 3).
Fig. 5. Effect pathway analysis revealing the nature of direct and indirect routes by which economic growth affects animal and plant biodiversity loss. A single sign denotes a linear relation, while a combination of two signs represents nonlinear quadratic behavior. See Tables 1 and 2 for coefficient values.

(a)

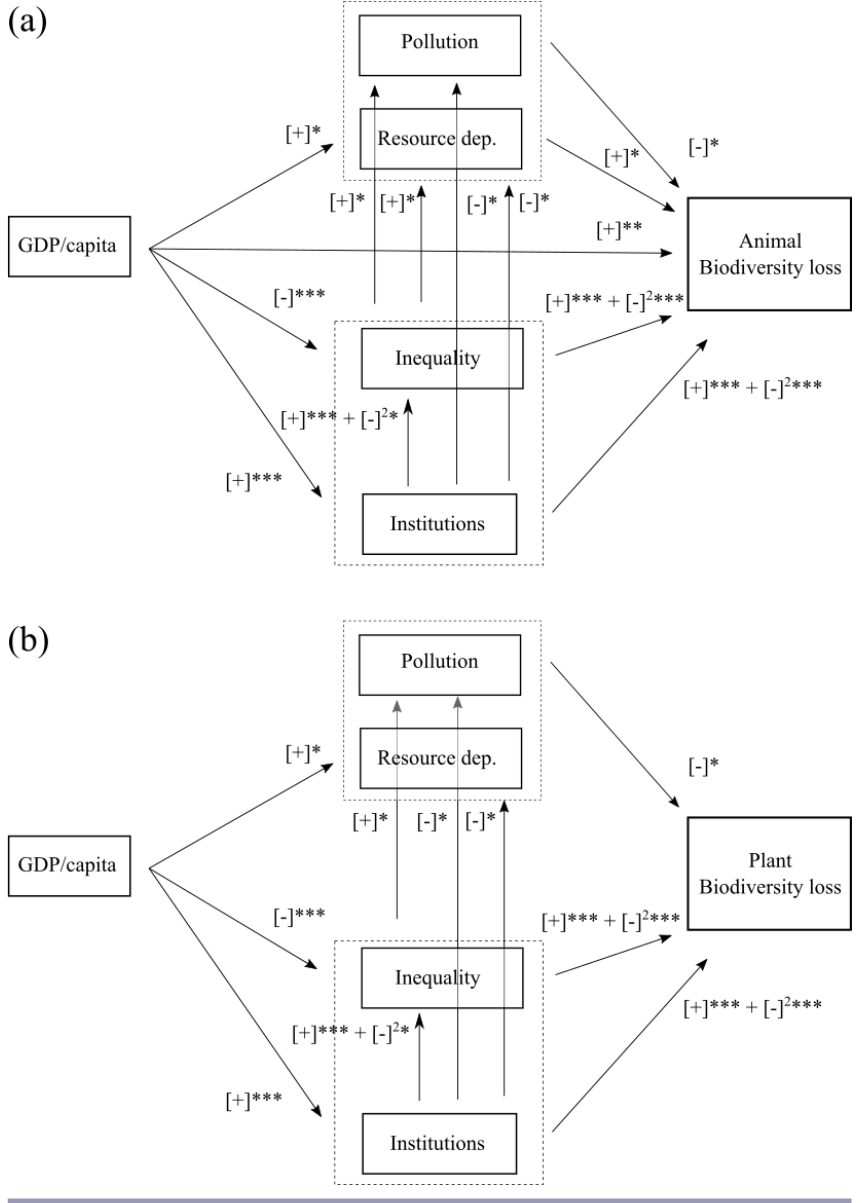

GDP per capita is significant across all specified models that explain animal biodiversity loss and has a significant positive direct effect (Table 2). An increase in GDP per capita (economic growth) leads to an increase in biodiversity loss. Furthermore, for animals, we find that the indirect effects of GDP per capita are mediated through the level of inequality, the strength of institutions, natural resource depletion, and pollution. These mediating indirect effects can be in the opposite direction from direct effects, depicting a trade-off. For example, economic growth harms animal biodiversity directly but also improves the strength of institutions that in turns helps biodiversity. In some cases, the mediating indirect effect can be reinforced by the direct effect. For example, institutions improve biodiversity both directly and also indirectly by reducing inequality.

For plants, however, the story is slightly different. We do not find any direct effects of GDP per capita on biodiversity. The effect of GDP per capita on plant biodiversity loss is mediated through intermediary variables such as inequality, the strength of institutions, natural resource depletion, and pollution (Fig. 5 and 
Table 2. Model results for animal biodiversity loss (direct and indirect effects).

\begin{tabular}{|c|c|c|c|c|c|}
\hline & $\begin{array}{c}\text { Model 1 } \\
\text { Panel (Within) } \\
\text { Ani. biodiv. loss (log) }\end{array}$ & $\begin{array}{c}\text { Model 2 } \\
\text { Panel (GMM) } \\
\text { Institutional Strength }\end{array}$ & $\begin{array}{c}\text { Model } 3 \\
\text { Panel (GMM) } \\
\text { Inequality }\end{array}$ & $\begin{array}{c}\text { Model } 4 \\
\text { Panel (GMM) } \\
\text { Natural Res. Dep. (log) }\end{array}$ & $\begin{array}{c}\text { Model } 5 \\
\text { Panel (GMM) } \\
\text { Pollution (log) }\end{array}$ \\
\hline Inequality & $\begin{array}{c}0.053 * * * \\
(0.015)\end{array}$ & & & $\begin{array}{l}0.120 * \\
(0.068)\end{array}$ & $\begin{array}{l}0.013 * \\
(0.007)\end{array}$ \\
\hline Inequality $^{2}$ & $\begin{array}{c}-0.001 * * * \\
(0.000)\end{array}$ & & & & \\
\hline Institutional Strength & $\begin{array}{c}0.025 * * * \\
(0.004)\end{array}$ & & $\begin{array}{c}0.467 * * * \\
(0.140)\end{array}$ & $\begin{array}{c}-0.073^{*} \\
(0.034)\end{array}$ & $\begin{array}{c}-0.013 * \\
(0.006)\end{array}$ \\
\hline Institutional Strength ${ }^{2}$ & $\begin{array}{c}-0.000^{* * *} \\
(0.000)\end{array}$ & & $\begin{array}{c}-0.003^{*} \\
(0.001)\end{array}$ & & \\
\hline Population (log) & $\begin{array}{c}0.126 * * * \\
(0.015)\end{array}$ & & & & \\
\hline Pollution (log) & $\begin{array}{c}-0.091 * \\
(0.037)\end{array}$ & & & & \\
\hline Natural Res. Dep. (log) & $\begin{array}{l}0.013^{*} \\
(0.008)\end{array}$ & & & & \\
\hline GDP/capita (log) & $\begin{array}{c}0.078 * * \\
(0.027)\end{array}$ & $\begin{array}{c}18.971 * * * \\
(1.471)\end{array}$ & $\begin{array}{c}-6.878^{* * *} \\
(1.203)\end{array}$ & $\begin{array}{l}1.567 * \\
(0.867)\end{array}$ & $\begin{array}{c}0.005 \\
(0.139)\end{array}$ \\
\hline Num. obs. & 542 & 542 & 542 & 542 & 542 \\
\hline Sargan Test: & & 15.124 & 46.359 & 61.681 & 25.593 \\
\hline Chisq, $\mathrm{p}$-value & & 0.516 & 0.694 & 0.380 & 0.109 \\
\hline Wald Test: & & $166.258 * * *$ & $59.989 * * *$ & $9.393^{*}$ & $36.379 * * *$ \\
\hline Chisq, p-value & & 0.000 & 0.000 & 0.024 & 0.000 \\
\hline Wald Test Time Dummies: & & $34.546 * * *$ & $29.891 * * *$ & $39.792 * * *$ & $19.121 * *$ \\
\hline Chisq, $\mathrm{p}$-value & & 0.000 & 0.000 & 0.000 & 0.004 \\
\hline
\end{tabular}

Table 3). The direction of mediating indirect effects is consistent with the earlier discussed case of animal biodiversity, despite for plants the effects of GDP per capita is fully explained by the mediating variables.

Across both cases for plants and animals, the significant negative effect of pollution on biodiversity loss is surprising and counterintuitive. One possible reason is that our measure tracks air pollution specifically and not environmental impact or ecological footprint, which irrevocably has a strong direct relationship with biodiversity loss (Mikkelson 2019). A second possible explanation is that pollution is a result of intensification (more intensive use of existing resources), while biodiversity loss is more the results of extensification (expanding use of resources). If economic growth leads to more intensification rather than extensification, it would provide space for biodiversity to bounce back, thus leading to lower losses. A finer spatial analysis than used in this paper could shed light on this issue. In a similar vein, the polycentric nature of governance arrangements across scales can also be a potential explanatory factor. According to Ozymy and Rey (2013), centralized institutions are good at managing air pollution, however, for biodiversity conservation, decentralized solutions are needed. So the institutional setting may be such that biodiversity conservation can go hand in hand with worsened air pollution performance.

Next, we look closer at the role of intermediary variables, beyond the linear effect. For institutions, the results confirm the inverted U-shaped relationship on biodiversity loss, evidenced by the highly significant negative quadratic coefficients (Fig. 5). Institutions also have an indirect effect on biodiversity, mediated through inequality, which is also inverted U-shaped in nature. Because both the direct and indirect effects between institutions and biodiversity loss are nonlinear, the net effect on biodiversity loss is ambiguous and depends on both the strength of institutions and the level of inequality in society.

For inequality, although the inverted U-shaped effect on biodiversity is present, the nonlinearity is more significant for the plant than animal biodiversity loss. However, as we saw earlier from the GAM results, the nonlinear component in inequality, in general, is weaker as compared with institutions, implying that biodiversity loss normally increases with inequality, and the turning point is located only at very high inequality levels. Moreover, in addition to the direct effect, inequality also affects biodiversity loss indirectly via both pollution and natural resource depletion for animals and via only pollution for plants. Here we see a reinforcing direct-indirect effect where inequality aggravates both resource depletion and pollution, which in turn increases biodiversity loss.

\section{DISCUSSION}

The effects of economic inequality on institutional strength and vice versa, are well studied (Easterly 2001, Keefer and Knack 2002, Chong and Gradstein 2007). Income concentrated in the hands of the few grants access to power and political influence that can inhibit institutional evolution (Glaeser et al. 2003), while a transparent society with effective institutions, promotes equality and justice in the distribution of economic gains (Gradstein 2007). We probe the mutually counteracting relationship (Chong and Gradstein 2007) between inequality and institutions further, asking how this interaction might play a role in explaining the effects of economic growth on the biodiversity loss.

We find an inverted U-shaped relationship between institutional strength and inequality, a result consistent with the literature 
Table 3. Model results for plant biodiversity loss (direct and indirect effects).

\begin{tabular}{|c|c|c|c|c|c|}
\hline & $\begin{array}{c}\text { Model 1 } \\
\text { Panel (linear) } \\
\text { Pla. biodiv. loss (log) }\end{array}$ & $\begin{array}{c}\text { Model } 2 \\
\text { Panel (GMM) } \\
\text { Institutional Strength } \\
\end{array}$ & $\begin{array}{c}\text { Model } 3 \\
\text { Panel (GMM) } \\
\text { Inequality } \\
\end{array}$ & $\begin{array}{c}\text { Model } 4 \\
\text { Panel (GMM) } \\
\text { Natural Res. Dep. (log) } \\
\end{array}$ & $\begin{array}{c}\text { Model } 5 \\
\text { Panel (GMM) } \\
\text { Pollution (log) } \\
\end{array}$ \\
\hline Inequality & $\begin{array}{c}0.340 * * * \\
(0.040)\end{array}$ & & & $\begin{array}{c}0.127 \\
(0.085)\end{array}$ & $\begin{array}{l}0.014^{*} \\
(0.006)\end{array}$ \\
\hline Inequality $^{2}$ & $\begin{array}{c}-0.004 * * * \\
(0.000)\end{array}$ & & & & \\
\hline Institutional Strength & $\begin{array}{c}0.038 * * * \\
(0.010)\end{array}$ & & $\begin{array}{c}0.456^{* * *} \\
(0.128)\end{array}$ & $\begin{array}{l}-0.064 * \\
(0.028)\end{array}$ & $\begin{array}{l}-0.014 * \\
(0.007)\end{array}$ \\
\hline Institutional Strength ${ }^{2}$ & $\begin{array}{c}-0.000^{* * *} \\
(0.000)\end{array}$ & & $\begin{array}{l}-0.002 * \\
(0.001)\end{array}$ & & \\
\hline Surface area $(\log )$ & $\begin{array}{c}0.116^{* *} \\
(0.044)\end{array}$ & & & & \\
\hline Precipitation (log) & $\begin{array}{c}0.440 * * * \\
(0.055)\end{array}$ & & & & \\
\hline Temperature & $\begin{array}{c}0.034 * * * \\
(0.007)\end{array}$ & & & & \\
\hline Population (log) & $\begin{array}{l}0.087^{*} \\
(0.045)\end{array}$ & & & & \\
\hline Pollution (log) & $\begin{array}{l}-0.238^{*} \\
(0.117)\end{array}$ & & & & \\
\hline GDP/capita (log) & & $\begin{array}{l}19.207 * * * \\
(1.329)\end{array}$ & $\begin{array}{l}-6.291 * * * \\
(1.224)\end{array}$ & $\begin{array}{l}1.538^{*} \\
(0.850)\end{array}$ & $\begin{array}{c}0.047 \\
(0.150)\end{array}$ \\
\hline Num. obs. & 527 & 527 & 527 & 527 & 527 \\
\hline Sargan Test: & & 22.752 & 49.983 & 58.948 & 28.622 \\
\hline Chisq, p-value & & 0.475 & 0.554 & 0.368 & 0.053 \\
\hline $\begin{array}{l}\text { Wald Test Coefficients: Chisq, p- } \\
\text { value }\end{array}$ & & $\begin{array}{l}208.782^{* * *} \\
0.000\end{array}$ & $\begin{array}{l}45.773^{* * * *} \\
0.000\end{array}$ & $\begin{array}{c}7.686^{*} \\
0.052\end{array}$ & $\begin{array}{l}34.764^{* * * *} \\
0.000\end{array}$ \\
\hline Wald Test Time Dummies: & & $33.588 * * *$ & $18.349^{* *}$ & $102.002 * * *$ & $17.070 * *$ \\
\hline Chisq, p-value & & 0.000 & 0.005 & 0.000 & 0.009 \\
\hline
\end{tabular}

(Chong and Calderón 2000). One interpretation of the causality behind this relationship is that institutional changes may initially favor the rich, because of the persistence of their power, but that subsequent improvements would lead to a level playing field for all (Acemoglu and Robinson 2008). The results suggest that this core mechanism drives further nonlinearities with respect to biosphere impact variables. With stronger institutions, biodiversity loss in both animal and plants seems to worsen first, before improving, depending on both the quality of institutions and level of inequality.

Additionally, in regions of high inequality, the potency of institutions withers away to protect biodiversity loss. This idea is supported by assertions in the literature pointing out that, while governance is important, it can be overshadowed by economic variables (Holland et al. 2009), and institutions may be less likely to regulate biosphere indicators, like biodiversity loss, in poor countries that are often unequal as well (Ostrom 2000).

Nonlinear relationships involving inequality are now commonly reported in the literature. The root of much of this work is in the ideas put forward by Kuznets (1955). Boyce (1994) was the first to hypothesize environmental degradation as a function of inequality, but later work showed that the effect of inequality and economic development can be highly complex and nonlinear (Scruggs 1998, Torras and Boyce 1998). The results suggest that both animal and plant biodiversity loss variables first deteriorate but then improve, in the institutions-inequality domain. Even though the improvements correlate with better institutions, this does not necessarily imply a causal relationship. Societal choices to mitigate biosphere impacts differ across regions and income levels (Scruggs 1998), so a comparison between countries may not necessarily reflect developments within countries over time. We mitigate this concern to use country-fixed effects in the GMM and time-invariant covariates, such as the land surface area in all other specifications. Even with strong institutions, highly unequal societies with concentrated power may be more likely to preclude an effective and enforceable consensus on environmental quality and conservation, thus reinforcing the status-quo of elites (Kashwan 2017).

Though economic growth positively strengthens institutions, the negative effect on inequality of economic growth needs to be interpreted with caution. Although most of the empirical literature using panel data do support a negative relationship between economic growth and inequality (Alesina and Rodrik 1994, Easterly 2001, Panizza 2002, Knowles 2005), there are suggestions of why this may be the result of an omitted variable bias or country-specific variables (Forbes 2000). Furthermore, an oft-quoted theoretical argument that economic growth will improve the overall income distribution by the "trickle-down effect" (Aghion and Bolton 1997), where more income is available to the poor as capital accumulation is achieved by economic growth, is also much disputed in recent years (Stiglitz 2015, Akinci 2018). For example, in some cases the growth-inequality relationship changes from negative to positive for developing and developed countries, respectively (Barro 2000), while others report complex and nonlinear changes (Banerjee and Duflo 2003, 
Huang et al. 2015). Although the exact specification of the growth-inequality relationship is still an open question, for the purpose of this paper we cautiously use the negative specification as estimated from our data, and focus on the mediation effect on biodiversity loss.

The results presented suggest that inequality and institutions play a central role in mediating the effects of economic growth on biodiversity loss. After taking into account the effects of inequality and institutions, we do not see a significant direct effect of economic growth on plant biodiversity loss and a dual direct and indirect effect on animal biodiversity loss. Furthermore, strong institutions can be fruitless in the face of rising inequality, where a highly unequal society can circumvent the system and choose to benefit at the expense of biodiversity. This interplay between institutions and inequality can be seen as a leverage point for sustainable transformation (Abson et al. 2017), especially now when most societies are in danger of operating outside their socalled "safe operating space" (Rockström et al. 2009). Focus on individual dimensions of sustainability in silos and ignoring indirect effects will provide a piecemeal image of the system, at best.

Discussion of structural relationships, explored in this paper, merits a note about causality, which is also very central in the literature on the Environmental Kuznets Curve (Brock and Taylor 2005). Defining causal interpretation when variables can be independently varied is easy, however in the real world, where causes are often interrelated and confounding unobserved variables are omnipresent, recovering causal effects by mere statistics are impractical. Statistical techniques like SEMs, "assume" causal relations between the variables of interest (Pearl 1998), which does not in any way mean SEM establishes causal relations from associations alone (Bollen and Pearl 2013). Here, the aim is to use the SEM framework to marshal support for the assumed structural relationships, not proving it. Significance of effects presented does not prove causality, however using a dynamic instrument variables approach with country fixed effects like GMM and controlling for observed covariates within the SEM framework, does make it more plausible. Nonetheless, the effects identified in this paper can be used to formulate hypotheses that could be carefully tested using experimental methods that are either natural (COVID-19 comes to mind) or carefully controlled. Together with more qualitative case studies, this will provide the evidence to test and solidify causal relationships.

\section{CONCLUSION}

We highlight the complex and nonlinear nature of the inequalityinstitutions interaction that can mediate impacts on the biosphere. The intertwined and coevolving nature of social-ecological interactions, though widely acknowledged, are not always well understood. In this paper, we have attempted to connect economic growth with effects on the biosphere in a multidimensional empirical framework. Within the constraints of available data and model simplicity, we are able to highlight the relationship that is important for action and relevant for policy. Focusing on institutions and inequality, as two key handles for policy, is of paramount importance, without which following a biosphere protection agenda can be wasteful and counterproductive.
Responses to this article can be read online at: https://www.ecologyandsociety.org/issues/responses. php/12078

\section{Acknowledgments:}

This project received funding from the European Union's Horizon 2020 research and innovation programme under the Marie Sklodowska-Curie grant agreement No 643073.

\section{Data Availability:}

Data and code used for the analysis and generating figures, are available and can be requested from the corresponding author. The analysis was carried out in $R$ (https://www.r-project.orgl) using the packages plm, PiecewiseSEM, and $m g c v$.

\section{LITERATURE CITED}

Abson, D. J., J. Fischer, J. Leventon, J. Newig, T. Schomerus, U. Vilsmaier, H. von Wehrden, P. Abernethy, C. D. Ives, N. W. Jager, and D. J. Lang. 2017. Leverage points for sustainability transformation. Ambio 46(1):30-39. https://doi.org/10.1007/ s13280-016-0800-y

Acemoglu, D., and J. A. Robinson. 2008. Persistence of power, elites, and institutions. American Economic Review 98(1):267-293. https://doi.org/10.1257/aer.98.1.267

Aghion, P., and P. Bolton. 1997. A theory of trickle-down growth and development. Review of Economic Studies 64(2):151-172. https://doi.org/10.2307/2971707

Akinci, M. 2018. Inequality and economic growth: trickle-down effect revisited. Development Policy Review 36:1-24. https://doi. org/10.1111/dpr.12214

Alesina, A., and D. Rodrik. 1994. Distributive politics and economic growth. Quarterly Journal of Economics 109 (2):465-490. https://doi.org/10.2307/2118470

Apostolopoulou, E., and W. M. Adams. 2017. Biodiversity offsetting and conservation: reframing nature to save it. Oryx 51 (1):23-31. https://doi.org/10.1017/S0030605315000782

Arrow, K., B. Bolin, R. Costanza, P. Dasgupta, C. Folke, C. S. Holling, B.-O. Jansson, S. Levin, K.-G. Mäler, C. Perrings, and D. Pimentel. 1996. Economic growth, carrying capacity, and the environment. Environment and Development Economics 1 (1):104-110. https://doi.org/10.1017/s1355770x00000413

Asafu-Adjaye, J. 2003. Biodiversity loss and economic growth: a cross-country analysis. Contemporary Economic Policy 21 (2):173-185. https://doi.org/10.1093/cep/byg003

Banerjee, A. V., and E. Duflo. 2003. Inequality and growth: What can the data say? Journal of Economic Growth 8(3):267-299. https://doi.org/10.1023/A:1026205114860

Barro, R. J. 2000. Inequality and growth in a panel of countries. Journal of Economic Growth 5(1):5-32. 
Blundell, R., and S. Bond. 1998. Initial conditions and moment restrictions in dynamic panel data models. Journal of Econometrics 87(1):115-143. https://doi.org/10.1920/wp.ifs.1995.9517

Bollen, K. A., and J. Pearl. 2013. Eight myths about causality and structural equation models. Pages 301-328 in S. L. Morgan, editor. Handbook of causal analysis for social research. Springer, Dordrecht, The Netherlands. https://doi.org/10.1007/978-94-007-6094-3_15

Bongaarts, J. 2019. IPBES, 2019. Summary for policymakers of the global assessment report on biodiversity and ecosystem services of the Intergovernmental Science-Policy Platform on Biodiversity and Ecosystem Services. Population and Development Review 45(3):680-681. https://doi.org/10.1111/padr.12283

Boyce, J. K. 1994. Inequality as a cause of environmental degradation. Ecological Economics 11:169-178. https://doi. org/10.1016/0921-8009(94)90198-8

Brock, W. A., and M. S. Taylor. 2005. Economic growth and the environment: a review of theory and empirics. Pages 1749-1821 in P. Aghion and S. N. Durlauf, editors. Handbook of economic growth. Vol. $1 \mathrm{~A}$. Elsevier, Amsterdam, The Netherlands.

Brum, F. T., C. H. Graham, G. C. Costa, S. B. Hedges, C. Penone, V. C. Radeloff, C. Rondinini, R. Loyola, and A. D. Davidson. 2017. Global priorities for conservation across multiple dimensions of mammalian diversity. Proceedings of the National Academy of Sciences of the United States of America 114:7641-7646. https://doi.org/10.1073/pnas.1706461114

Cardinale, B. J., J. E. Duffy, A. Gonzalez, D. U. Hooper, C. Perrings, P. Venail, A. Narwani, G. M. Mace, D. Tilman, D. A. Wardle, A. P. Kinzig, G. C. Daily, M. Loreau, J. B. Grace, A. Larigauderie, D. S. Srivastava, and S. Naeem. 2012. Biodiversity loss and its impact on humanity. Nature 486:59-67. https://doi. org/10.1038/nature11148

Carpenter, S. R., H. A. Mooney, J. Agard, D. Capistrano, R. S. DeFries, S. Diaz, T. Dietz, A. K. Duraiappah, A. Oteng-Yeboah, H. M. Pereira, C. Perrings, W. V. Reid, J. Sarukhan, R. J. Scholes, and A. Whyte. 2009. Science for managing ecosystem services: beyond the Millennium Ecosystem Assessment. Proceedings of the National Academy of Sciences 106:1305-1312. https://doi. org/10.1073/pnas.0808772106

Chong, A., and C. Calderón. 2000. Institutional quality and income distribution. Economic Development and Cultural Change 48(4):761-786. https://doi.org/10.1086/452476

Chong, A., and M. Gradstein. 2007. Inequality and institutions. Review of Economics and Statistics 89(3):454-465. https://doi. org/10.1162/rest.89.3.454

Crist, E., C. Mora, and R. Engelman. 2017. The interaction of human population, food production, and biodiversity protection. Science 356(6335):260-264. https://doi.org/10.1126/science.aal2011

Dasgupta, P., A. P. Kinzig, and C. Perrings. 2013. The value of biodiversity. Pages 167-179 in S. A. Levin, editor. Encyclopedia of biodiversity. Second Edition. Academic, Cambridge, Massachusetts, USA. https://doi.org/10.1016/B978-0-12-384719-5.00372-5
Dietz, S., and W. N. Adger. 2003. Economic growth, biodiversity loss and conservation effort. Journal of Environmental Management 68(1):23-35. https://doi.org/10.1016/S0301-4797 (02)00231-1

Easterly, W. 2001. The middle class consensus and economic development. Journal of Economic Growth 6(4):317-335. https:// doi.org/10.1023/A:1012786330095

Easterly, W., J. Ritzen, and M. Woolcock. 2006. Social cohesion, institutions, and growth. Economics and Politics 18(2):103-120. https://doi.org/10.1111/j.1468-0343.2006.00165.x

Folke, C., Å. Jansson, J. Rockström, P. Olsson, S. R. Carpenter, F. S. Chapin III, A. S. Crépin, G. Daily, K. Danell, J. Ebbesson, T. Elmqvist, V. Galaz, F. Moberg, M. Nilsson, H. Österblom, E. Ostrom, Å. Persson, G. Peterson, S. Polasky, W. Steffen, B. Walker, and F. Westley. 2011. Reconnecting to the biosphere. Ambio 40:719. https://doi.org/10.1007/s13280-011-0184-y

Forbes, K. J. 2000. A reassessment of the relationship between inequality and growth. American Economic Review 90(4):869-887. https://doi.org/10.1257/aer.90.4.869

Gini, C. 1912. Variabilità e Mutuabilità. Contributo allo Studio delle Distribuzioni e delle Relazioni Statistiche. Tipografia di P. Cuppini, Bologna, Italy.

Glaeser, E., J. Scheinkman, and A. Shleifer. 2003. The injustice of inequality. Journal of Monetary Economics 50(1):199-222. https://doi.org/10.1016/S0304-3932(02)00204-0

Grace, J. B. 2006. Structural equation modeling and natural systems. Cambridge University Press, Cambridge, UK. https:// doi.org/10.1017/CBO9780511617799

Gradstein, M. 2007. Inequality, democracy and the protection of property rights. Economic Journal 117(516):252-269. https://doi. org/10.1111/j.1468-0297.2007.02010.x

Grossman, G. M., and A. B. Krueger. 1995. Economic growth and the environment. Quarterly Journal of Economics 110 (2):353-377. https://doi.org/10.2307/2118443

Heerink, N., A. Mulatu, and E. Bulte. 2001. Income inequality and the environment: aggregation bias in environmental Kuznets curves. Ecological Economics 38(3):359-367. https://doi. org/10.1016/S0921-8009(01)00171-9

Holland, T. G., G. D. Peterson, and A. Gonzalez. 2009. A crossnational analysis of how economic inequality predicts biodiversity loss. Conservation Biology 23(5):1304-1313. https:// doi.org/10.1111/j.1523-1739.2009.01207.X

Hooper, D. U., E. C. Adair, B. J. Cardinale, J. E. K. Byrnes, B. A. Hungate, K. L. Matulich, A. Gonzalez, J. E. Duffy, L. Gamfeldt, and M. I. Connor. 2012. A global synthesis reveals biodiversity loss as a major driver of ecosystem change. Nature 486 (7401):105-108. https://doi.org/10.1038/nature11118

Huang, H. C., W. S. Fang, S. M. Miller, and C. C. Yeh. 2015. The effect of growth volatility on income inequality. Economic Modelling 45:212-222. https://doi.org/10.1016/j.econmod.2014.11.020

Kashwan, P. 2017. Inequality, democracy, and the environment: a cross-national analysis. Ecological Economics 131:139-151. https://doi.org/10.1016/j.ecolecon.2016.08.018 
Keefer, P., and S. Knack. 2002. Polarization, politics and property rights: links between inequality and growth. Public Choice 111 (1-2):127-154. https://doi.org/10.1023/A:1015168000336

Klooster, D. 2000. Institutional choice, community, and struggle: a case study of forest co-management in Mexico. World Development 28(1):1-20. https://doi.org/10.1016/S0305-750X(99) 00108-4

Knowles, S. 2005. Inequality and economic growth: the empirical relationship reconsidered in the light of comparable data. Journal of Development Studies 41(1):135-159. https://doi. org/10.1080/0022038042000276590

Kuznets, S. 1955. Economic growth and income inequality. American Economic Review 45(1):1-28.

Leach, M., R. Mearns, and I. Scoones. 1999. Environmental entitlements: dynamics and institutions in community-based natural resource management. World Development 27(2):225-247. https://doi.org/10.1016/S0305-750X(98)00141-7

Lefcheck, J. S. 2016. piecewiseSEM: Piecewise structural equation modelling in R for ecology, evolution, and systematics. Methods in Ecology and Evolution 7(5):573-579. https://doi. org/10.1111/2041-210X.12512

Mazor, T., C. Doropoulos, F. Schwarzmueller, D. W. Gladish, N. Kumaran, K. Merkel, M. Di Marco, and V. Gagic. 2018. Global mismatch of policy and research on drivers of biodiversity loss. Nature Ecology and Evolution 2(7):1071-1074. https://doi. org/10.1038/s41559-018-0563-X

Mehlum, H., K. Moene, and R. Torvik. 2006. Cursed by resources or institutions? World Economy 29(8):1117-1131. https://doi. org/10.1111/j.1467-9701.2006.00808.x

Mikkelson, G. M. 2019. Invisible hand or ecological footprint? Comparing social versus environmental impacts of recent economic growth. Organization and Environment. https://doi. org/10.1177/1086026619885111

Mikkelson, G. M., A. Gonzalez, and G. D. Peterson. 2007. Economic inequality predicts biodiversity loss. PLOS ONE 2(5): e444. https://doi.org/10.1371/journal.pone.0000444

Mills, J. H., and T. A. Waite. 2009. Economic prosperity, biodiversity conservation, and the environmental Kuznets curve. Ecological Economics 68(7):2087-2095. https://doi.org/10.1016/j. ecolecon.2009.01.017

Mirza, M. U., A. Richter, E. H. van Nes, and M. Scheffer. 2019. Technology driven inequality leads to poverty and resource depletion. Ecological Economics 160:215-226. https://doi. org/10.1016/j.ecolecon.2019.02.015

Naidoo, R., and W. L. Adamowicz. 2001. Effects of economic prosperity on numbers of threatened species. Conservation Biology 15(4):1021-1029. https://doi.org/10.1046/

j.1523-1739.2001.0150041021.x

Ostrom, E. 2000. Reformulating the commons. Swiss Political Science Review 6(1):29-52. https://doi.org/10.1002/j.1662-6370.2000. tb00285.x

Ostrom, E. 2009. A general framework for analyzing sustainability of social-ecological systems. Science 325 (5939):419-422. https://doi.org/10.1126/science.1172133
Ozymy, J., and D. Rey. 2013. Wild spaces or polluted places: contentious policies, consensus institutions, and environmental performance in industrialized democracies. Global Environmental Politics 13(4):81-100. https://doi.org/10.1162/GLEP_a_00199

Panizza, U. 2002. Income inequality and economic growth: evidence from American data. Journal of Economic Growth 7 (1):25-41. https://doi.org/10.1023/A:1013414509803

Pearl, J. 1998. Graphs, causality, and structural equation models. Sociological Methods and Research 27(2):226-284. https://doi. org/10.1177/0049124198027002004

Rockström, J., W. Steffen, K. Noone, Å. Persson, F. S. Chapin, E. F. Lambin, T. M. Lenton, M. Scheffer, C. Folke, H. J. Schellnhuber, B. Nykvist, C. A. De Wit, T. Hughes, S. Van Der Leeuw, H. Rodhe, S. Sörlin, P. K. Snyder, R. Costanza, U. Svedin, M. Falkenmark, L. Karlberg, R. W. Corell, V. J. Fabry, J. Hansen, B. Walker, D. Liverman, K. Richardson, P. Crutzen, and J. A. Foley. 2009. A safe operating space for humanity. Nature 461 (7263):472-475. https://doi.org/10.1038/461472a

Rogowski, R., and D. C. MacRae. 2008. Inequality and institutions: What theory, history, and (some) data tell us. Pages 354-386 in P. Beramendi and C. J. Anderson, editors. Democracy, inequality, and representation: a comparative perspective. Russell Sage Foundation, New York, New York, USA.

Scruggs, L. A. 1998. Political and economic inequality and the environment. Ecological Economics 26(3):259-275. https://doi. org/10.1016/S0921-8009(97)00118-3

Shafik, N. 1994. Economic development and environmental quality: an econometric analysis. Oxford Economic Papers 46:757-773. https://doi.org/10.1093/oep/46.Supplement_1.757

Soulé, M. E. 1985. What is conservation biology? A new synthetic discipline addresses the dynamics and problems of perturbed species, communities, and ecosystems. BioScience 35(11):727-734. https://doi.org/10.2307/1310054

Steffen, W., J. Rockström, K. Richardson, T. M. Lenton, C. Folke, D. Liverman, C. P. Summerhayes, A. D. Barnosky, S. E. Cornell, M. Crucifix, J. F. Donges, I. Fetzer, S. J. Lade, M. Scheffer, R. Winkelmann, and H. J. Schellnhuber. 2018. Trajectories of the Earth system in the Anthropocene. Proceedings of the National Academy of Sciences of the United States of America 115 (33):8252-8259. https://doi.org/10.1073/pnas.1810141115

Stiglitz, J. E. 2015. Inequality and economic growth. Political Quarterly 86:134-155. https://doi.org/10.1111/1467-923X.12237

Torras, M., and J. K. Boyce. 1998. Income, inequality, and pollution: a reassessment of the environmental Kuznets curve. Ecological Economics 25(2):147-160. https://doi.org/10.1016/ $\underline{\mathrm{S} 0921-8009(97) 00177-8}$

Vucetich, J. A., J. T. Bruskotter, and M. P. Nelson. 2015. Evaluating whether nature's intrinsic value is an axiom of or anathema to conservation. Conservation Biology 29(2):321-332. https://doi.org/10.1111/cobi.12464

Washington, H., and M. Maloney. 2020. The need for ecological ethics in a new ecological economics. Ecological Economics 169:106478. https://doi.org/10.1016/i.ecolecon.2019.106478 
Windmeijer, F. 2005. A finite sample correction for the variance of linear efficient two-step GMM estimators. Journal of Econometrics 126(1):25-51. https://doi.org/10.1016/j.jeconom.2004.02.005

Wood, S. N. 2006. Low-rank scale-invariant tensor product smooths for generalized additive mixed models. Biometrics 62 (4):1025-1036. https://doi.org/10.1111/j.1541-0420.2006.00574.x

Wood, S. N. 2017. Generalized additive models: an introduction with $R$, Second edition. CRC, Boca Raton, Florida, USA. 